\title{
Knowledge and Awareness Level of Contraceptive Usage Among Adolescents in Mankranso of Ahafo-Ano South District
}

\author{
Abena Serwaa Ofosu ${ }^{1}$ and Napoleon Bellua Sam (PhD) ${ }^{2 *}$ \\ ${ }^{1}$ Department of Nursing, Kokofu Nursing Training College, Kokofu, Ghana \\ ${ }^{2}$ Students Information System Unit, University for Development Studies, Tamale, Ghana
}

*Corresponding author: Napoleon Bellua Sam, Students Information System Unit, University for Development Studies,

Tamale, Ghana

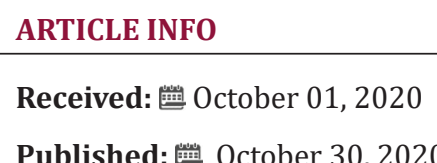

Citation: Abena Serwaa Ofosu, Napoleon Bellua Sam. Knowledge and Awareness Level of Contraceptive Usage Among Adolescents in Mankranso of Ahafo-Ano South District. Biomed J Sci \& Tech Res 31(4)-2020. BJSTR. MS.ID.005123.

Keywords: Contraceptive; Cross-Sectional Study; Stigmatization; Adolescent; Teenage Pregnancy; Jadelle and Implanon

\section{ABSTRACT}

Objectives: There is a major health and social problem in Ghana as a result of high levels of teenage pregnancy. Contraceptive use in Ghana among the adolescents is low and few studies have researched into it. The purpose of this study was to assess the level of knowledge, awareness and attitude towards the practice of contraception of the adolescents' in Mankranso, Ghana. This is a cross-sectional study with a structured questionnaire. The responses were scored and analysed using Statistical Package for Social Sciences (SPSS) version 20.

Results: This study revealed that most of the adolescents lack knowledge about modern contraceptives such as jadelle and implanon. Majority of the respondents (94\%) indicated that they have never used any contraception before. The main contraceptive device observed to have been used by respondents was condom (10\%).Most of them strongly agreed that the use of contraceptive by a girl before her first birth can lead to infertility and use of condom does not make sex enjoyable. Religious doctrine and stigmatization were strongly agreed with index of $85 \%$ and $84 \%$ respectively as challenges faced by adolescents in seeking contraceptive services.

Conclusion: This study showed that the level of knowledge on contraceptives usage among the adolescent was low. The usage of modern contraceptives was not preferred based on the negative attitude they have about contraceptives.

\section{Introduction}

\section{Background to the Study}

Adolescence may constitute a period of both disorientation and discovery. The transitional duration may portray matters of freedom and self-identity; many adolescents and their peers face tough choices with respect to school activity, sex life, drugs, alcohol, and social life. Age groups, romantic looks and outward appearances normally tend to rise during teen's journey toward adulthood. Motivating adolescent persons to find and use contraception is a universal public health concern. There is a great vacuum for contraception need and thus transforms into increased numbers of unplanned pregnancies and also a rise in maternal mortality in nations with poor maternal health delivery schemes. Therefore, bridging the great vacuum for contraception need is a vital focus in millennium development goal five. Internationally, plans are far advanced to cover up the great vacuum for contraception need; however, some countries see the progress in a very slowest pace [1].

In Ghana, there is a low patronage of contraceptive in adolescents because sexual maturity and introduction of sexual actions start at a younger age. This situation results in increase number of teenage pregnancies that constitute a huge health and social challenge in Ghana [2]. In spite of government policies to decrease the number of unintended pregnancies by ensuring contraception as a primary human right, the figure of adolescent pregnancies in Ghana remains increased. It is worth to note that 
a society with a great percentage of sexually active adolescents may possibly result into serious threat of pregnancies. The junior and senior high school pupils who engage in unprotected sexual activities as a result of risk-engaging conducts are becoming susceptible to Sexually Transmitted Infections (STIs), Human Immunodeficiency Virus (HIV)/Acquired Immune Deficiency Syndrome (AIDS) and unintended pregnancies. Most of the females at the age of nineteen (19) and below constitute thehuge-risk group of poor pregnancy outcomes in some part in Africa [3]. The rates of unsafe sexual practices and pregnancies are mainly great in junior and senior high school students in the villages in Ghana in which the use of contraception is still connected to religion. Huge number of adolescents is unable to access contraceptive, even though the services are freely accessible in the entire country.

Most pregnancies in senior high schools are unintended and as a result aborted unlawfully. This may be as a result of ignorance, lack of information and panic in adolescents' stage. This establishes a need to create awareness on adolescent sexual health reproduction. Adolescent pregnancy may be disadvantageous to individuals as well as the Country. Adolescents are of a higher peril than the adults in respect to infant birth weights, pre-term births, and infant deaths. Adolescent mothers are expected to record more of low level school achievements and high school dropout. Teenage mothers' children are obvious to continue a cycle of disadvantage where the likelihood of giving birth as teenagers will be high $[4,5]$ In Mankranso most adolescents are not able to complete the basic level to the senior high level due to unwanted pregnancies. In 2013, out of the total Antenatal Care (ANC) attendance, 772 were adolescent from the district, 28 had both unsafe and safe abortion. Another data obtained from the district education office concerning school enrolment revealed that, many of the junior high pupils drop out at the primary level. All the four (4) basic schools in Mankranso have a total population of 1304 pupils at the primary level but have 471 pupils at the junior high school level, the number continue to reduce at the Senior High School (SHS ) level [6]. Adolescents are likely to be at peril for unplanned pregnancies, so identifying their level of information on contraceptives and conveying information to them is essential to prevent such pregnancies and underscores the need to carry out this study in Mankranso, Ghana.

\section{Methodology}

This study used a descriptive cross sectional study design and was carried out at Mankranso of AhafoAno- South District. This study was conducted at Mankranso because it has a lot of recorded cases of teenage pregnancies. The target population of this study was made up of adolescents from both public and private Junior Secondary Schools in Mankranso. We selected two hundred (200) pupils from the JHS 1 and 2 in four different schools using stratified and simple random technique. Fifty (50) pupils were selected from each school, they were grouped into two distinct classes, males and females, and were selected randomly by labelling 25 pieces of papers 1 and 0 .Those who selected the Figure 1 were selected for the study. A structured questionnaire was used to collect the data. The questionnaires were divided into six (6) sections: sections A, B, C, D, E, and F. The first section, requires information on Socio-Demographic Data such as respondent's school, gender, age, marital status, religious background, number of children and age at menarche or sperm Arche. The other sections covered knowledge/awareness and usage of contraception, sources of information about contraceptives, attitude towards contraception and challenges adolescent face in seeking contraceptives services. The questionnaires were piloted to establish its reliability before the administration. Samples of the questionnaire were pre-tested at Atwima Koforidua JHS to show its effectiveness. The questionnaires were tested on 20 adolescents from the JHS, who had similar characteristics as those in the actual study. The responses helped to refine the instrument for administration. A written permission was sought from the heads of institution where this study was carried out. The questionnaires were administered personally with the help of the guidance and counselling coordinators and other teachers to avoid any bias. Informed consent was obtained from each respondent. The quantitative data collected using the questionnaire were scored and analysed using Statistical Package for Social Sciences (SPSS) version 20 software. Descriptive statistics was used in analyzing the data (Frequencies with percentages, mean and standard deviation) and relative Importance Index (RII). The mean score matrix defined per observation per construct was developed to give a summarized view showing responses per respondent. Relative index was computed to measure how each variable was faring in relation to the other ranked from the variable that respondents scaled as very true to those they indicated as very untrue.

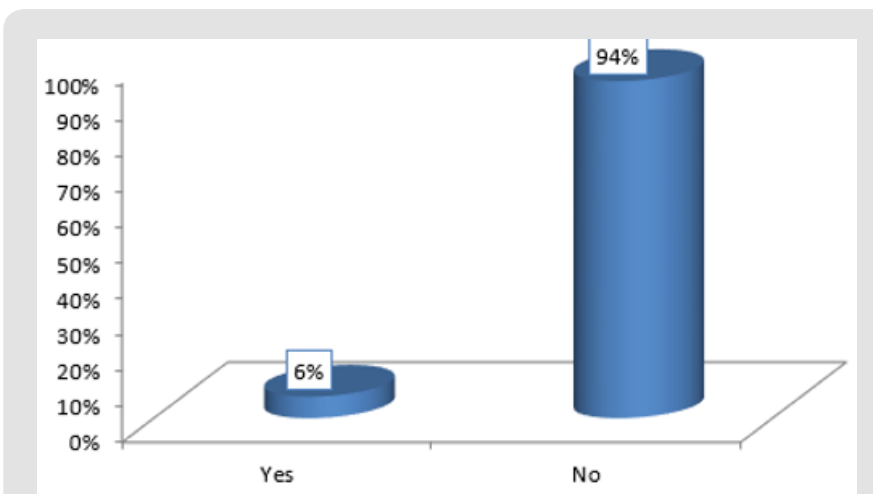

Figure 1: Have you ever used any method of contraception showed that $94 \%$ of the respondents indicated they have never used any contraception. While $6 \%$ indicated they have use contraception before.

\section{Results}

\section{Socio-Demographic Data}

Table 1 presents the results of the demographic data of the respondents. It was observed that $52 \%$ were in the age group of 
12-14 years, $42 \%$ were in the age group of $15-17$ years and $6 \%$ were in the age group 18-20 years. The study covered 50\% male and $50 \%$ female which showed gender balance. All the respondents were singles. The study observed $50 \%$ representing charismatic/ Pentecostal Christians, 41\%representing Catholic/Anglican Christians and $9 \%$ representing Islam. The study investigated the age respondents had their menarche first menstruation or spermarche (first ejaculation). It was observed that $73 \%$ representing majority of the respondents had their menarche first menstruation or spermarche (first ejaculation) at the age between $12-14$ years. It was revealed $18 \%$ had it between age group of $15-$ 17 years, $6 \%$ also had it at age group 18-20 years and those who had it below 12 years were $5 \%$. It was observed that about $97 \%$ of the respondents had no children. However, $2.5 \%$ indicated they have 1-2 children.

Table 1: Socio-Demographic Data.

\begin{tabular}{|c|c|c|c|}
\hline Variables & Categories & Frequency & $\%$ \\
\hline \multirow{5}{*}{ Name of school } & DA 1 & 50 & $25 \%$ \\
\hline & DA 2 & 50 & $25 \%$ \\
\hline & Holy Prophet & 50 & $25 \%$ \\
\hline & Methodist JHS & 50 & $25 \%$ \\
\hline & Total & 200 & $100 \%$ \\
\hline \multirow{4}{*}{ Age of Respondents } & $12-14$ & 116 & $52 \%$ \\
\hline & $15-17$ & 84 & $42 \%$ \\
\hline & $18-20$ & 11 & $6 \%$ \\
\hline & Total & 200 & $100 \%$ \\
\hline \multirow{3}{*}{ Sex of Respondents } & Male & 100 & $50 \%$ \\
\hline & Female & 100 & $50 \%$ \\
\hline & Total & 200 & $100 \%$ \\
\hline \multirow{2}{*}{ Marital status } & Single & 200 & $100 \%$ \\
\hline & Total & 200 & $100 \%$ \\
\hline \multirow{4}{*}{ Religious Background } & $\begin{array}{l}\text { Catholic/ } \\
\text { Anglican }\end{array}$ & 82 & $41 \%$ \\
\hline & Islam & 18 & $9 \%$ \\
\hline & $\begin{array}{c}\text { Charismatic/ } \\
\text { Pentecostal }\end{array}$ & 100 & $50 \%$ \\
\hline & Total & 200 & $100 \%$ \\
\hline \multirow{5}{*}{$\begin{array}{c}\text { At what age did you } \\
\text { have your menarche } \\
\text { (first menstruation) } \\
\text { or spermarche (first } \\
\text { ejaculation) }\end{array}$} & Below 12 & 9 & $5 \%$ \\
\hline & $12-14$ & 145 & $73 \%$ \\
\hline & $15-17$ & 35 & $18 \%$ \\
\hline & $18-20$ & 11 & $6 \%$ \\
\hline & Total & 200 & $100 \%$ \\
\hline \multirow{3}{*}{$\begin{array}{c}\text { How many children do } \\
\text { you have }\end{array}$} & None & 195 & $98 \%$ \\
\hline & $1-2$ & 5 & $2 \%$ \\
\hline & Total & 200 & $100 \%$ \\
\hline
\end{tabular}

\section{Knowledge the Adolescent have about Contraception}

Table 2 The mean score for I lack knowledge about jadelle and implanon and its use was 3.5 showing respondents averagely indicated it as very true approximately. This means that students lack knowledge about jadelle and implanon and its use. Its index was $88 \%$ indicating averagely students indicated the statement to be very true. I have heard of contraception before had mean score of 3.3 showing respondents averagely indicated as true. It had index of $82 \%$ which showed respondents indicated the statement to be very true. Students have heard about contraception before. The following variables had mean scores ranging from 2.5 to 2.9 approximately 3 . I lack knowledge about contraceptives, I received information about contraceptives, I know I can obtain contraceptives services and I know more about condom and its uses. They were ranked from $3 \mathrm{rd}$ to 6 th with indexes ranging from $72 \%$ to $62 \%$. These statements were indicated as true. Rank 4, 5, 6 showed respondents have knowledge about contraception and its use as they indicated them to be true. However, ranked 3; I lack knowledge about contraceptives was also indicated as true which means they lack knowledge about contraception and its use. I had education on possible side effects with the current contraceptive methods, I know much more about the contraceptive method I want to use and I Know more about pills and injectable were ranked from $7^{\text {th }}$ to $9^{\text {th }}$ with mean score ranging from 2 to 2.4 and indexes ranging from $50 \%$ to $61 \%$. They were observed to be indicated as untrue statement by the respondents averagely. The last two statements were also indicated as untrue statement. These variables indicated that respondents do not have knowledge about contraceptives

Table 2: Knowledge Adolescent have about ContraceptionStatistics and Relative Index.

\begin{tabular}{|c|c|c|c|c|c|c|}
\hline & N & Mean & $\begin{array}{c}\text { Std. } \\
\text { Deviation }\end{array}$ & Sum & RII & Ranking \\
\hline $\begin{array}{c}\text { I lack } \\
\text { knowledge } \\
\text { about jadelle } \\
\text { and implanon } \\
\text { and its use }\end{array}$ & 200 & 3.5 & 1.042 & 700 & 88 & 1 \\
\hline $\begin{array}{c}\text { I have heard of } \\
\text { contraception } \\
\text { before }\end{array}$ & 200 & 3.3 & 0.70 & 654 & 82 & 2 \\
\hline $\begin{array}{c}\text { I lack } \\
\text { knowledge } \\
\text { about } \\
\text { contraceptives }\end{array}$ & 200 & 2.9 & 0.735 & 578 & 72 & 3 \\
\hline $\begin{array}{c}\text { I received } \\
\text { information } \\
\text { about } \\
\text { contraceptives }\end{array}$ & 200 & 2.7 & 0.938 & 542 & 68 & 4 \\
\hline $\begin{array}{c}\text { I know I } \\
\text { can obtain } \\
\text { contraceptives } \\
\text { services }\end{array}$ & 200 & 2.6 & 1.084 & 520 & 65 & 5 \\
\hline $\begin{array}{c}\text { I know more } \\
\text { about condom } \\
\text { and its uses }\end{array}$ & 200 & 2.5 & 0.789 & 496 & 62 & 6 \\
\hline $\begin{array}{c}\text { I had education } \\
\text { on possible } \\
\text { side effects } \\
\text { with the } \\
\text { current } \\
\text { contraceptive } \\
\text { methods }\end{array}$ & 200 & 2.4 & 1.034 & 485 & 61 & 7 \\
\hline
\end{tabular}




\begin{tabular}{|c|l|l|l|l|l|l|}
\hline $\begin{array}{c}\text { I know much } \\
\text { more about the } \\
\text { contraceptive } \\
\text { method I want } \\
\text { to use }\end{array}$ & 200 & 2.4 & 0.713 & 476 & 60 & 8 \\
\hline $\begin{array}{c}\text { I Know more } \\
\text { about pills and } \\
\text { injectable }\end{array}$ & 200 & 2.0 & 0.844 & 396 & 50 & 9 \\
\hline $\begin{array}{c}\text { I am told } \\
\text { what to do } \\
\text { if I have any } \\
\text { problem with } \\
\text { the current } \\
\text { contraceptive } \\
\text { methods }\end{array}$ & 200 & 1.9 & 0.579 & 371 & 46 & 10 \\
\hline $\begin{array}{c}\text { I has } \\
\text { knowledge } \\
\text { about vaginal } \\
\text { spermicides } \\
\text { and its uses }\end{array}$ & 200 & 1.4 & 0.665 & 280 & 35 & 11 \\
\hline
\end{tabular}

\section{Usage of Contraceptives among Adolescents}

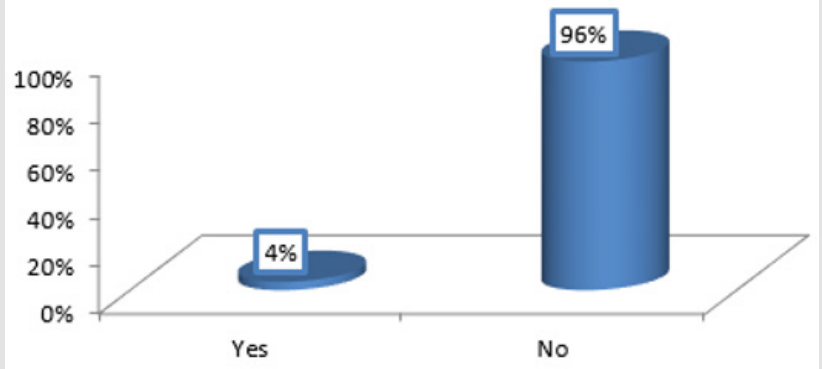

Figure 2: Are you currently using contraceptive method.

It was observed as at the time of the study that only $4 \%$ of the total number of the respondents was currently using contraceptives (Figure 2). Out of the sixteen contraceptive methods listed for the respondents to indicate the ones they have ever used, five of them were identified to have been used before withdrawal, abstinence, pills, condom and oral intake of herbs. It was observed that $6 \%$ of the respondents have used withdrawals, $8 \%$ of them have used oral intake of herbs, pill $3 \%$, and condom $10 \%$ and $73 \%$ indicated abstinence. The main contraception observed to have been used by respondents was abstinence 146 (73\%) which was very infective since most adolescent were sexually active and it was a period they normally want to be with the opposite sex (Figures 3\&4). There were different sources of information observed from the results that respondents get to know about contraceptives. Majority of the respondents, representing $79 \%$ said they obtained the information through teachers. The next two main sources were television and parents representing respectively $71 \%$ and $70 \%$ of the respondents as indicated. It was observed that $49 \%$ indicated their friend gave them the information on contraceptives. It was observed that 42 $\%$ of the respondents indicated they had the information from school counsellors. The results suggest that mass media continues to be another main source of information for young people. There is also relatively weak dependence on interactive communication with parents or family members for sexual and reproductive health information. It was indicated by few respondents that their source of information about contraceptive were romantic partners, internet and magazines/books/print media (Figure 5). Most of the respondents(83\%) indicated that one can get contraceptive from hospital/FP clinic/RCH. About 73\% also indicated one can get it from pharmacy/chemical shop.

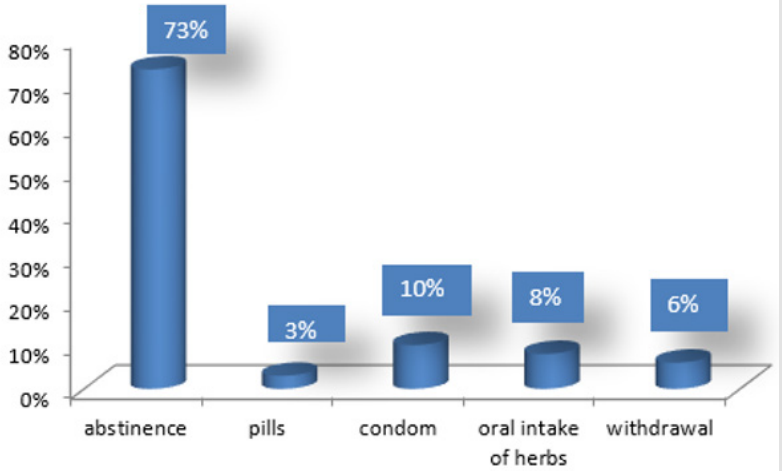

Figure 3: Contraceptive methods respondents have ever used.

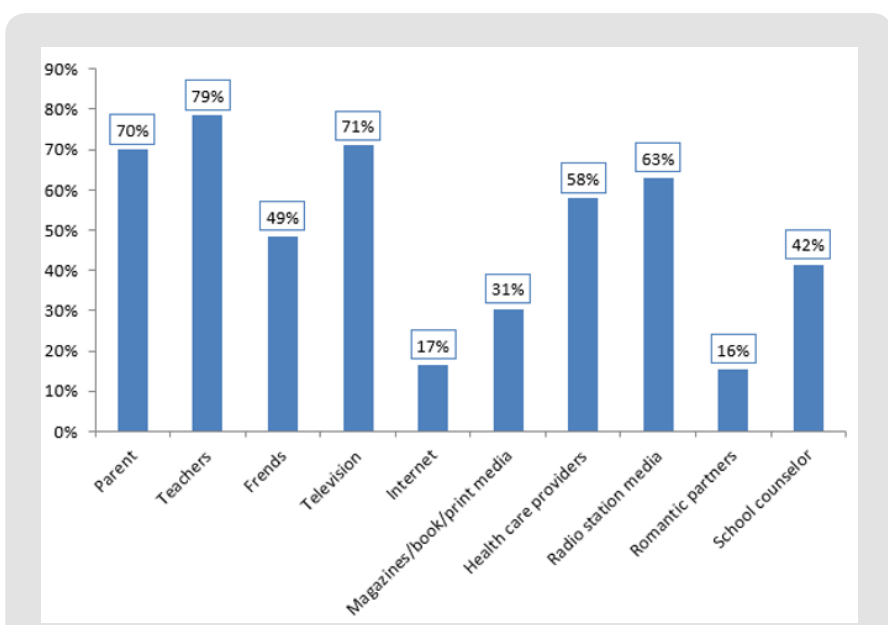

Figure 4: Source of information about contraception.

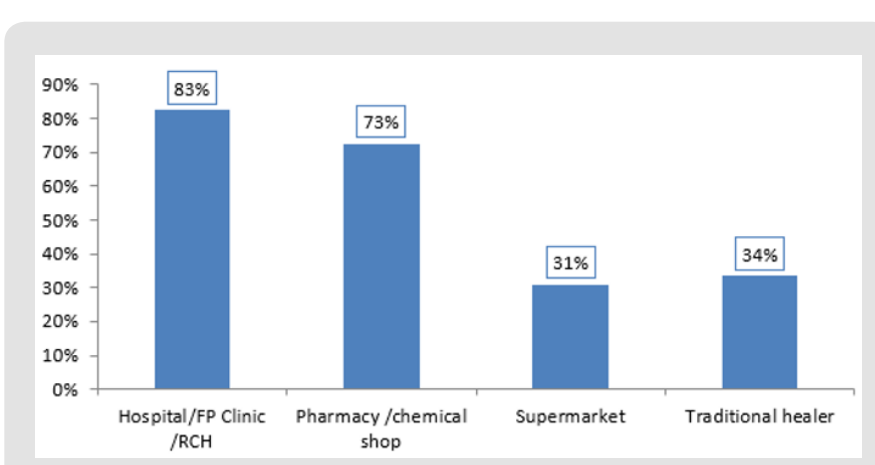

Figure 5: Where to get contraceptive to use.

\section{Attitude Towards Contraception}

It was observed from the results in Table 3 that $67 \%$ of the respondents strongly agree that the use of contraceptive by a girl 
before her first birth can lead to infertility. It could be seen that 21 $\%$ agreed and $16 \%$ were uncertain. About $5 \%$ strongly disagreed that the use of contraceptive by a girl before her first birth can lead to infertility. The statement that people who insist on condom use are promiscuous was strongly agreed by $66 \%$ of the respondents and $11 \%$ agreed. Those who at least agreed were about $77 \%$ forming majority of the respondents. It was also observed that $71 \%$ of the respondents at least agreed with the statement that sex is not enjoyable when they use condom. Again, $13 \%$ each strongly disagree and disagree that sex is not enjoyable when they use condom, whereas $17 \%$ were uncertain. These findings confirm the perception that condom usage is unnatural. Contraception usage is against my religion was strongly agreed by $56 \%$ of the respondents. It was observed that $11 \%$ also agreed, showing that at least $67 \%$ of the respondents agree that their religious believe is against the use of contraceptives. Majority of the respondents strongly agreed and agreed that adolescent should seek parent consent to obtain contraceptive method, representing $49 \%$ and $16 \%$ respectively. This means that $65 \%$ of the respondents at least agreed that adolescent should seek parent consent to obtain contraceptive method.

Table 3: Attitude Towards Contraception-Frequency with \%age.

\begin{tabular}{|c|c|c|c|c|c|c|}
\hline & Strongly Disagree & Disagree & Uncertain & Agree & $\begin{array}{l}\text { Strongly } \\
\text { Agree }\end{array}$ & Total \\
\hline \multirow{2}{*}{ 1. I approve of the use of contraception } & 16 & 38 & 25 & 31 & 80 & 190 \\
\hline & $8 \%$ & $20 \%$ & $13 \%$ & $16 \%$ & $42 \%$ & $100 \%$ \\
\hline \multirow{2}{*}{$\begin{array}{l}\text { 2. Use of contraception is important for adolescent } \\
\text { having sex }\end{array}$} & 32 & 17 & 25 & 38 & 78 & 190 \\
\hline & $17 \%$ & $9 \%$ & $13 \%$ & $20 \%$ & $41 \%$ & $100 \%$ \\
\hline \multirow{2}{*}{ 3. Contraception usage is against my religion } & 24 & 24 & 19 & 21 & 112 & 200 \\
\hline & $12 \%$ & $12 \%$ & $10 \%$ & $11 \%$ & $56 \%$ & $100 \%$ \\
\hline \multirow{2}{*}{$\begin{array}{l}\text { 4. Adolescent should seek parent consent to obtain } \\
\text { contraceptive method }\end{array}$} & 25 & 26 & 20 & 31 & 97 & 199 \\
\hline & $13 \%$ & $13 \%$ & $10 \%$ & $16 \%$ & $49 \%$ & $100 \%$ \\
\hline \multirow{2}{*}{$\begin{array}{l}\text { 5. Use of contraceptive by a girl before her first birth can } \\
\text { lead to infertility }\end{array}$} & 10 & 0 & 16 & 41 & 133 & 200 \\
\hline & $5 \%$ & $0 \%$ & $8 \%$ & $21 \%$ & $67 \%$ & $100 \%$ \\
\hline \multirow{2}{*}{ 6. Sex is not enjoyable when I use condom } & 16 & 10 & 33 & 21 & 120 & 200 \\
\hline & $8 \%$ & $5 \%$ & $17 \%$ & $11 \%$ & $60 \%$ & $100 \%$ \\
\hline \multirow{2}{*}{ 7. People who insist on condom use are promiscuous } & 11 & 30 & 6 & 21 & 132 & 200 \\
\hline & $6 \%$ & $15 \%$ & $3 \%$ & $11 \%$ & $66 \%$ & $100 \%$ \\
\hline
\end{tabular}

Use of contraception is important for adolescent having sex was also strongly agreed by $41 \%$ of the respondents and $20 \%$ agreed. The mean scores and the standard deviation of each measure of agreement have been presented in Table 4 , as well as the relative index. It was observed that the use of contraceptive by a girl before her first birth can lead to infertility had a mean score of 4.43 with low standard deviation showing averagely students agree to the statement. The relative index was observed to be high, thus 89
$\%$ being ranked first among the variables. The second ranked among the variables was People who insist on condom use are promiscuous with index of $83 \%$ and mean score of 4.17. Sex is not enjoyable when I use condom was also significantly agreed by respondents with index of $82 \%$ and mean score of 4.1 . This means that averagely respondents agreed to the statement "sex is not enjoyable when I use condom".

Table 4: Attitude Towards Contraception - Descriptive Statistics and Index.

\begin{tabular}{|c|c|c|c|c|c|c|}
\hline & $\mathbf{N}$ & Sum & Mean & Std. Deviation & RII & Ranking \\
\hline $\begin{array}{l}\text { 1. Use of contraceptive by a girl before her first birth can lead to } \\
\text { infertility }\end{array}$ & 200 & 887 & 4.43 & 1.005 & 89 & 1 \\
\hline 2. People who insist on condom use are promiscuous & 200 & 833 & 4.17 & 1.329 & 83 & 2 \\
\hline 3. Sex is not enjoyable when I use condom & 200 & 819 & 4.1 & 1.298 & 82 & 3 \\
\hline 4. Contraception usage is against my religio0n & 200 & 773 & 3.86 & 1.486 & 77 & 4 \\
\hline $\begin{array}{l}\text { 5. Adolescent should seek parent consent to obtain contraceptive } \\
\text { method }\end{array}$ & 199 & 746 & 3.75 & 1.48 & 75 & 5 \\
\hline 6. Use of contraception is important for adolescent having sex & 190 & 683 & 3.59 & 1.504 & 72 & 6 \\
\hline 7. I approve of the use of contraception & 190 & 435 & 2.29 & 1.375 & 46 & 7 \\
\hline
\end{tabular}




\section{Challenges the Adolescents Face in Seeking Contraceptives Services}

The results in Table 5, demonstrated the challenges adolescents face a lot in seeking contraceptive services. The most challenges observed among them were challenges ranked from one to four. The challenge, it is against my Religious doctrine was averagely scaled as strongly agreed with index of $85 \%$. The second ranked challenge faced by adolescents was stigmatization against the use of contraceptive which was averagely indicated with index of $84 \%$. This showed that averagely respondents strongly agreed stigmatization against the use of contraceptive was challenge face by adolescent in seeking contraceptive services. Cost of some form of contraceptives and I do experience headaches were ranked third and fourth respectively with indexes of $81 \%$ and $80 \%$. Rankings of challenges from $5^{\text {th }}$ to $8^{\text {th }}$; thus, reversal surgery is difficult expensive and not available in most areas, unfriendly and judgmental attitude of health care providers, health centre are often far from home or difficult to get toand frequent breastfeeding create inconveniences for especially adolescent girl who are in school were indicated by respondents averagely agreed, with indexes ranging from $76 \%$ to $72 \%$ and mean scores from 3.82 to 3.61 . Statements ranked from 9 to 13 were observed that averagely respondents were uncertain about them. Their mean scores ranged from 3.31 to 3.09 and indexes ranged from $66 \%$ to $62 \%$.

Table 5: Challenges the Adolescents Face in Seeking Contraceptives Services.

\begin{tabular}{|c|c|c|c|c|c|c|}
\hline Descriptive Statistics & $\mathbf{N}$ & Sum & Mean & Std. Deviation & RII & Ranking \\
\hline 1. It is against my Religious doctrine & 200 & 850 & 4.25 & 1.111 & 85 & 1 \\
\hline 2. Stigmatization against the use of contraceptive & 200 & 838 & 4.19 & 1.077 & 84 & 2 \\
\hline 3. Cost of some form of contraceptives & 195 & 792 & 4.06 & 1.073 & 81 & 3 \\
\hline 4. I do experience headaches & 200 & 797 & 3.99 & 1.18 & 80 & 4 \\
\hline $\begin{array}{l}\text { 5. Reversal surgery is difficult expensive and not available in } \\
\text { most areas }\end{array}$ & 200 & 764 & 3.82 & 1.111 & 76 & 5 \\
\hline 6. Unfriendly and judgmental attitude of health care providers & 200 & 737 & 3.69 & 1.03 & 74 & 6 \\
\hline 7. Health center are often far from home or difficult to get to & 200 & 725 & 3.63 & 1.029 & 73 & 7 \\
\hline $\begin{array}{l}\text { 8. Frequent breastfeeding creates inconveniences for especially } \\
\text { adolescent girl who are in school }\end{array}$ & 200 & 722 & 3.61 & 1.164 & 72 & 8 \\
\hline 9. Some method requires minor surgery to insert or remove & 200 & 663 & 3.31 & 1.096 & 66 & 9 \\
\hline 10. I do experience irregular menstrual bleeding & 200 & 641 & 3.2 & 0.791 & 64 & 10 \\
\hline 11. I do experience dizziness & 200 & 636 & 3.18 & 1.016 & 64 & 11 \\
\hline 12. I do experience weight gain or loss & 200 & 631 & 3.16 & 1.199 & 63 & 12 \\
\hline 13. Inadequate health facilities and lack of privacy & 200 & 618 & 3.09 & 1.249 & 62 & 13 \\
\hline
\end{tabular}

\section{Discussion}

According to the available literature, a study conducted by Araoye et al. [4] involving 971 students of both sex aged 18-24 years who attended a University in Nigeria indicated that males representing $97.7 \%$ and females representing $98.4 \%$ knew at least one method of contraception. It had index of $82 \%$ which showed respondents indicated the statement to be very true. Students have heard about contraception before. These findings were in line with our study that indicated pre knowledge of contraception by students. The following variables had mean scores ranging from 2.5 to 2.9 approximately 3. I lack knowledge about contraceptives, I received information about contraceptives, I know I can obtain contraceptives services and I know more about condom and its uses. They were ranked from 3rd to 6th with indexes ranging from $72 \%$ to $62 \%$. These statements were indicated as true. Even though, this study showed some respondents have knowledge about contraception and its use, most students lack knowledge about contraception and its use. In a study conducted by Bozkurt et al. [7] on 385 adolescents about the knowledge and attitude towards emergency contraception, fifty percent of the respondents were conversant with various choices to prevent pregnancy after unsafe sex, but they required specific knowledge about possible methods and ways to use them. Our study also showed that most respondents have never used any contraception while few indicated they have use contraception before. This finding was consistent with the level of sexual knowledge among senior high school students in Ekpoma as revealed by [8]. The study indicated that students in senior high school become sexually sensitive even at a younger age of 9 years. A boy or girl of 7 years knows little or nothing about their body anatomy well enough to be able to know signs of pregnancy. Considering this background, the use of contraception during sexual intercourse is usually not considered due to their low level of awareness of its safety. Most of the sexually sensitive students were not even prepared for sex when it happened since it occurred out of curiosity. Another study by Aggarwal et al., [9] in Delhi, reported on a contraception awareness rate of $83.5 \%$, 
comparable to similar study findings in Ludhiana and Nigeria of 2,388 Nigerian undergraduate students, it was reported that $87 \%$ had had sex, but only $34 \%$ had used some method of contraception. This study further revealed that the main contraception observed to have been used by respondents was abstinence which was very infective since most adolescent were sexually active and it was the period they normally want to be with the opposite sex. This finding was consistent with World Health Organisation (WHO) [10], which suggested that many adolescents believe they were too young to become pregnant. Many also refuse to use contraceptives and instead rely on the probability of conceiving at a given time of the month or knowledge of their ovulation period. In an article published in Global Development Professionals Network in 2014 that examined contraception use among adolescent girls, Venkatraman ChandraMouli and Karlien Braet [11] found out that adolescents in many places have misconceptions about health effects of contraceptives, including their future ability to bear children. As a result, they tend to prefer traditional remedies or to use ineffective methods such as withdrawal. Condom is the most observed contraceptive used, representing $10 \%$.

Our study revealed the main sources of adolescent knowledge via teachers, television, parents, radio station (media) and health care providers. According to the available literature, result from the 2008 Ghana Demographic and Health Survey [12] showed that, 26\% of 15-19 years olds had heard of family planning from both radio and television and among the people who were exposed to radio message on family planning, 75\% approved of the message. Results from GDHS [12] also showed that less than half of adolescent males and females have heard or seen family planning in the mass media via community forum. Previous studies [13-16] have indicated that the commonest source of information about contraception was through friends, health institution and family planning clinics despite the fact that these are dedicated specifically to such duties. Information obtained from friends about the use and practice of contraception is often misleading as they contain a lot of misinformation, distortion, falsehood and misconceptions, and often at times self-centered $[15,17]$.

The relative index of 'use of contraceptive by a girl before her first birth can lead to infertility' was observed to be high, thus was ranked first among the variables in this study. This finding was consistent with an article published in The Guardian: Global Development Professionals Network in 2014 that examined contraception use among adolescent girls, Venkatraman ChandraMouli and Karlien Braet [11] found out that erratic availability, cost, laws and policies prevent unmarried adolescents in low and middle income countries from accessing contraceptives. Even when there were no legal restrictions, health workers often refused to provide unmarried adolescents with contraceptives because they did not approve of premarital sex. And when they did provide contraceptives, they often limit these to condoms, wrongly believing that long-acting hormonal methods and intra- uterine devices were inappropriate for all young women and those who had no children. Even when adolescents were able to obtain contraceptive methods, social pressure might prevent their use. In the same study they found out that adolescents in many places have misconceptions about health effects of contraceptives, including their future ability to bear children. Again, this study revealed that people who insist on condom use are promiscuous with index of 83 $\%$ and mean score of 4.17 was ranked second among the variables. This finding tallied with Adinma et al. [18] who apparently made a similar observation that girls who did carry condoms around might be perceived as being sexually available; a situation that would reduce their eligibility as potential wives. Such beliefs have been found to produce a strong negative influence on condom use among University Nigerians. Some girls feel that a partner's wish to use condom suggests that, they are not clean and that they are commercial sex workers or that they are involved in more sexual relationship. This study revealed that most of the respondents agreed to the fact that sex is not enjoyable when they use condom. This finding was also consistent with a study by Agyei and Epema [19] that condom reduced pleasure or sensation and that their use indicated a general lack of respect for the female partner. This study also revealed that the most challenges adolescents face in seeking contraceptive services were religious doctrine, stigmatization, Cost of some form of contraceptives and they do experience headaches being ranked from one to four, respectively. In partnership with Impatient Optimists, on youth perspectives to celebrate World Contraception Day 2012, Idrissa A. Conteh found out The Challenges Facing Sierra Leone's Youth are the stigma surrounding contraception prevents their use by adolescents who are not in stable relationships and some forms of contraception which are also unaffordable and poorly stocked [20].

\section{Conclusion}

This study found out that the level and attitude towards the use of contraceptives among adolescents is very low and only few of them have ever used or currently using effective contraceptive methods. Their main source of getting information on contraception is their teachers, followed by television and others. Very few of them get information on contraception from the internet. Most of them are not using modern contraceptives due to the negative attitude they have about contraceptives, they strongly agreed that the use of contraceptive by a girl before her first birth can lead to infertility and the use of condom does not make sex enjoyable.

\section{References}

1. Ghana news agency (2012) Ghana Statistical Service releases census results. Regional news on Friday, 1 June 2012. http://www.ghanaweb. com.

2. (2000) Ghana Demographic and Health Survey (GDHS), Annual Report.

3. Onyensoh 0, Govender I, Tumbo J (2013) Knowledge of, Attitudes Towards, and Practices of Contraception in High School Pupils in Tswaing Sub District, North West Province. Southern Africa Journal of Epidemiology and Infection 28(4): 227-232. 
4. Araoye MO, Fakeye O, Jolayemi ET (1998) Contraception Method Choices among Adolescents in a Nigerian Tertiary Institution. West Africa Journal of Medicine 17: 227-231

5. (2013) Ghana Demographic and Health Survey (GDHS), Annual Report.

6. (2013) District profile, reproductive and child health (RCH) data (2012 and 2013), Ahafo-Ano South district-Mankranso. District Health Administration.

7. Bozkurt N, Korucuoglu U, Aksakal FN, Biri A (2006) Turkish adolescents knowledge on and attitude toward emergency contraception. Journal of Paediatric, Adolescent and Gynaecology19(6): 391-395.

8. Idonije BO,Oluba OM, Otamere HO (2011) A Study on Knowledge Attitude and Practice of Contraception among Secondary Schoo Students in Ekpoma. Nigeria JPCS 2(6): 22-27.

9. Aggarwal O, Sharma AK, Chhabra P (2000) A Study in Sexuality of Medical College Students India. Journal of adolescent health 26(3): 226229.

10. (2005) World Health Organisation. Risk and Protective factors Affecting Adolescent reproductive Health in the Developing World. Available at www.who.int.

11. Chandra Mouli V, Karlien B (2014) Progress Review: Contraception Use among Adolescent Girls. The Guardian 17 February 2014. Available at www.theguardian.com.

12. (2008) Ghana National Reproductive Health, Annual Report.

\section{ISSN: 2574-1241}

DOI: $10.26717 /$ BJSTR.2020.31.005123

Napoleon Bellua Sam. Biomed J Sci \& Tech Res

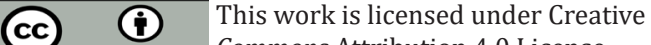
Commons Attribution 4.0 License

Submission Link: https://biomedres.us/submit-manuscript.php
13. Josaphat B, Florence M, Elisabeth F, Kristin G (2006) Emergency contraception and fertility awareness among university students in Kampala, Uganda. East Afr Med J 6(4): 194-200.

14. Byamugisha JK, Mirembe FM, Faxelid E, Gemzell Danielsson K (2006) Emergency Contraception, Fertility Awareness among University Students in Kampala Uganda. Afri Health Sci 6(4): 194-200.

15. Abiodun PA, Adisa AF, Aderemi IM (2001) Knowledge and Previous Contraceptive use by Pregnant Teenagers in Ilorin Nigeria Trop. Journal of Obstetrics and Gynaecology 18 (2): 73-77.

16. Nworah JAO (2010) Knowledge, Attitude and Practices of Emergency Contraception Among Students in Tertiary Schools in Anambra State Southeast Nigeria. Int Med Sci 2(1): 1-4.

17. Baker GN, Rioh S (1992) Influences on Adolescent Sexuality in Nigeria and Kenya: Findings from Recent-Group Discussion Studies. Studying Family Planning 23(3): 199-210.

18. Adinma JI, Agbai AO, Okeke AO, Okaro JM (1999) Contraception in teenage Nigerian School girls. Adv contraceptives 15: 283-291.

19. Agyei WKA, Epema E (1990) Adolescent Fertility in Kampala. Knowledge, Perception and Practice in Biology and Society. Pub Med 7(4): 203-214.

20. Conteh IA (2012) World contraception day: The Challenges Facing Sierra Leone's Youth. Impatient Optimists Blog: World Contraception Day www.impatientoptimists.org.

$\begin{array}{ll}\text { BIOMEDICAL } & \text { Assets of Publishing with us } \\ \text { RESEARCHES } & \text { - Global archiving of articles } \\ \text { - Immediate, unrestricted online access }\end{array}$

